\title{
PERAN KEGIATAN MENGECAP DALAM MENGEMBANGKAN KREATIVITAS ANAK USIA 5-6 TAHUN
}

\author{
Farida Iksan11, Rosita Wondal2², Umikalsum Arfa3 ${ }^{3}$ \\ Universitas Khairun Ternate \\ Fakultas Keguruan dan Ilmu Pendidikan \\ Jl. Bandarah Sultan Babullah Kota Ternate Utara, Kotak Pos 53 Ternate 977328 \\ Telpon: (0921) 3110905-Faksimili 0921-3110901 \\ Email: faridaiksan16@gmail.com¹, rositawondal80@gmail.com², \\ umikalsumarfa@gmail.com³
}

\begin{abstract}
Abstrak
Kreativitas sangat penting dimiliki oleh seorang individu termasuk pada anak usia dini yang merupakan genarasi penerus bangsa. Oleh karena itu kreativitas perlu dikembangkan sejak dini dengan berbagai kegiatan. Salah satu kegiatan yang dapat membantu mengembangkan kreativitas anak yaitu dengan kegiatan mengecap. Penelitian kajian literatur ini dilakukan dengan tujuan untuk mengkaji tentang peran kegiatan mengecap dengan menggunakan alat dan bahan alam di lingkungan sekitar (buah belimbing dan pelepah pisang) dalam rangka mengembangkan kreativitas anak. Hasil yang diperoleh dari kajian ini adalah kegiatan mengecap dengan menggunakan buah belimbing dan pelepah pisang berperan dalam mengembangkan kreativitas anak. Dengan kegiatan mengecap, kemampuan imajinasi anak akan berkembang untuk menuangkan ide-ide baru, anak mampu berpikir dan membentuk suatu karya yang baru dan menarik.
\end{abstract}

Kata Kunci: Kegiatan Mengecap, Kreativitas Anak

\begin{abstract}
The creativities are certainly substantial to everyone as personal instead of children such as the next generation of the nation. In this case, needs the creativity to develop children throughout any activities at an early age. The stamp is the one activity that can help to enhance children's creativity. This research of literature examines the main role of stamp activity throughout the tools and materials of the environment surrounding (Star fruit and stem of the banana bunch) in the development of children's' creativity. The results of this research are the activities using Star fruit and the stem of the banana bunch in the development of children's creativity. By using stamp activity, will develop children's skills of imagination to explore new ideas, creative thinking, and create new things and interesting.
\end{abstract}

Keywords: Stamp activity, Children's creativity.

\section{A. Pendahuluan}

Dunia pendidikan sedang berusaha untuk menciptakan generasi yang kreatif agar dapat mengembangkan potensi-potensi yang ada pada diri setiap anak didik agar dapat berguna bagi diri sendiri maupun orang lain. Bagi diri sendiri, kreativitas penting sebagai perwujudan diri, yang merupakan salah satu kebutuhan pokok manusia. Bagi orang lain, hasil-hasil pemikiran maupun hasil karya yang kreatif dapat berguna untuk meningkatkan taraf hidup masyarakat. Oleh sebab itu sangat diperlukan usaha pengembangan kreativitas sedini mungkin, yaitu pada masa-masa golden age (Turyani dan Wondal, 2018). Pendidikan anak usia dini (PAUD) merupakan suatu upaya pembinaan yang ditujukan kepada anak sejak lahir sampai dengan usia 
enam tahun yang dilakukan melalui pemberian rangsangan pendidikan untuk membantu pertumbuhan dan perkembangan jasmani dan rohani, agar anak memiliki kesiapan dalam memasuki pendidikan lebih lanjut. Setiap manusia yang dilahirkan telah diberikan anugerah oleh Tuhan Yang Maha Esa berupa potensi-potensi yang tersembunyi (the hidden excellent potencies). Potensi tersebut memerlukan kesempatan untuk berkembang di dalam lingkungan yang menghargai, memupuk, dan menunjang kreativitas anak sejak dini.

Undang-Undang Nomor 23 Tahun 2003 tentang Sistem Pendidikan Nasional, pendidikan nasional bertujuan untuk mengembangkan potensi peserta didik agar menjadi manusia yang beriman dan bertaqwa kepada Tuhan Yang Maha Esa, berakhlak mulia, sehat, berilmu, cakap, kreatif, mandiri dan menjadi warga Negara yang demokratis serta bertanggung jawab. Demikian pula dalam GBHN 1993 dinyatakan bahwa pengembangan kreativitas hendaknya dimulai pada usia dini, yaitu di lingkungan keluarga sebagai tempat pendidikan pertama dan dalam pendidikan prasekolah. Secara eksplisit dinyatakan pada setiap tahap perkembangan anak dan pada setiap jenjang pendidikan, mulai dari pendidikan prasekolah sampai di perguruan tinggi. Kreativitas perlu dipupuk, dikembangkan dan ditingkatkan disamping mengembangkan kecerdasan dan ciri-ciri lain yang menunjang pembangunan.

Pengembangan kreativitas sejalan dengan pengembangan kepribadian anak. Jika kreativitas anak berkembang dengan baik, maka anak akan mengalami perkembangan kepribadian yang sehat. Anak akan dapat mengembangkan kepribadian yang mandiri, percaya diri, dan produktif. Sebaliknya, jika kreativitas anak kurang dapat berkembang dengan baik, maka anak akan mengalami pertumbuhan kepribadian yang tergantung, kurang percaya diri, mudah putus asa, tidak memiliki keberanian dan tidak produktif (Lestari 2006; 20).

Mengingat betapa pentingnya seorang individu bahkan anak memiliki kreativitas, maka diperlukan adanya upaya dalam mengembangkan kreativitas anak tersebut. Salah satu kegiatan yang dapat mengambangkan kreativitas anak sejak dini adalah dengan kegiatan mengecap dengan menggunakan bahan alam yang tersedia disekitar anak. Mengecap dapat disebut juga mencetak merupakan salah satu kegiatan seni yang dapat mengembangkan kreativitas anak. Kegiatan mengecap ini dilakukan oleh anak dengan bahan-bahan yang disediakan oleh guru seperti pelepah pohon pisang dan buah belimbing yang dipotong melintang sehingga muncul motif yang akan dipakai sebagai cap. Cairan yang digunakan dalam kegiatan mengecap dapat diramu sendiri oleh guru dengan menggunakan pewarna yang dapat dibuat sendiri oleh guru dari bahan-bahan sekitar yang aman bagi anak. Sebagai contoh warna merah dapat diperoleh dari ekstrak buah naga, warna hijau dari daun pandan dan sebagainya. Kegiatan yang dilakukan dengan cara anak menggunakan pelepah buah yang sebelumnya sudah diberi warna kemudian ditempelkan pada kertas yang diberikan oleh guru.

Berdasarkan kenyataan dilapangan daerah Maluku Utara merupakan salah satu daerah yang memiliki kekayaan hayati yang banyak untuk dapat dimanfaatkan diberbagai bidang terutama pendidikan guna meningkatkan proses pembelajaran. Kekayaan hayati berupa tumbuhan masih jarang dimanfaatkan oleh guru PAUD dalam proses pembelajaran dikelas. Sebagian guru cenderung terpaku pada produk-produk pabrik ketimbang memanfaatkan lingkungan disekitar sebagai media pembelajaran. Pada penelitian kajian literatur penulis ingin membuat suatu kajian tentang peran kegiatan mengecap khususnya dalam mengembangkan kreativitas anak dengan menggunakan buah belimbing dan pelepah pisang yang tersedia bebas di lingkungan sekitar anak. 


\section{B. Pembahasan}

\section{Pengertian Kreativitas}

Kreativitas merupakan suatu kondisi, sikap atau keadaan yang sangat khusus sifatnya dan hampir tidak mungkin dirumuskan secara tuntas. Kreativitas dapat didefinisikan dalam beranekaragam pernyataan tergantung siapa dan bagaimana menyorotinya. Istilah kreativitas dalam kehidupan sehari-hari selalu dikaitkan dengan prestasi yang istimewa dalam menciptakan sesuatu yang baru, menemukan cara-cara pemecahan masalah yang tidak dapat ditemukan oleh kebanyakan orang, ide-ide baru, dan melihat adanya berbagai kemungkinan (Turyani dan Wondal, 2018).

Supriadi (2001) memaparkan bahwa kreativitas merupakan kemampuan sesorang untuk melahirkan sesuatu yang baru, baik berupa gagasan maupun karya nyata, yang relative berbeda dengan apa yang telah ada sebelumnya. Sementara itu, Munandar (1999) mengemukakan bahwa kreativitas adalah kemampuan untuk membuat kombinasi baru, berdasarkan data, informasi, atau unsur-unsur yang sudah ada atau sudah dikenal sebelumnya, yaitu semua pengalaman dan pengetahuan yang diperoleh seseorang selama hidupnya baik itu di lingkungan sekolah, keluarga, maupun dari lingkungan masyarakat.

Kreativitas pada anak adalah kemampuan untuk menghasilkan pemikiranpemikiran yang asli, tidak biasa, dan sangat fleksibel dalam merespon dan mengembangkan pemikiran dan aktivitas (Abdurrahman, 2005). Pada anak usia dini kreativitas akan terlihat jelas ketika anak bermain, dimana ia menciptakan berbagai bentuk karya, lukisan ataupun khayalan spontanitas dengan alat mainannya.

Pendapat lain mengungkapkan kreativitas yaitu menghasilkan sesuatu yang baru dan dapat dilihat atau didengar oleh orang lain (Frome dalam Abdussalam (2005:14). Kreativitas membuat seseorang untuk menghasilkan sesuatu yang baru. Artinya, kreativitas adalah kemampuan untuk menghasilkan sesuatu yang baru dan orisinil. Seorang anak mempunyai kreativitas yang berbeda-beda untuk menciptakan atau menghasilkan sesuatu sesuai dengan kemampuannya. Kreativitas mampu membuat seseorang menciptakan atau menghasilkan karya yang baru. Kreativitas menghasilkan ide baru, selain itu dapat menciptakan bermacam-macam hal baru dan asli (Bruce, 2004).

Susanto (2011:112) menyatakan kreativitas merupakan kemampuan umum untuk menciptakan sesuatu yang baru, baik berupa produk atau gagasan baru yang dapat diterapkan dalam memecahkan masalah, atau sebagai kemampuan untuk melihat unsur-unsur yang sudah ada sebelumnya.

Kreativitas mulai dengan kemampuan individu untuk menciptakan sesuatu yang baru. Menurut Gallagher dalam Masganti Sit, dkk (2016:1) menyatakan bahwa kreativitas berhubungan dengan kemampuan untuk menciptakan, mengadakan, menemukan suatu bentuk baru dan atau untuk menghasilkan sesuatu melalui keterampilan imajinatif, hal ini berarti kreativitas berhubungan dengan pengalaman mengekspresikan dan mengaktualisasikan identitas individu dalam bentuk terpadu dalam hubungan dengan diri sendiri, dengan alam dan orang lain.

Munandar (2009) memberikan empat alasan perlunya dikembangkan kreativitas pada anak yaitu:

a. Dengan berkreasi anak dapat mewujudkan dirinya dan ini merupakan kebutuhan pokok manusia. 
b. Kreativitas atau cara berpikir kreatif, dalam arti kemampuan untuk menemukan cara-cara baru dapat memecahkan suatu permasalahan.

c. Bersibuk diri secara kreatif tidak saja berguna tapi juga memberikan kepuasan pada individu. Hal ini terlihat jelas pada anak-anak yang bermain balok-balok atau permainan konstruktif lainnya.

d. Kreativitaslah yang memungkinkan manusia untuk meningkatkan kualitas dan taraf hidupnya. Dengan kreativitas seseorang terdorong untuk membuat ideide, penemuan-penemuan atau teknologi baru yang dapat meningkatkan kesejahteraan masyarakat secara luas.

Kreativitas sangat penting untuk dikembangkan karena kreativitas dapat meningkatkan prestasi akdemik (Yamamoto, 1964 dalam Palaniappan). Sehingga, semakin tinggi kreativitas yang dimiliki seseorang maka semakin tinggi pula prestasi akademik yang diraih. Kreativitas merupakan kombinasi dari inovasi, flexibilitas, dan sensitivitas yang membuat seseorang mampu berpikir produktif berdasarkan kepuasan pribadi dan kepuasan lainnya (Stenberg, dalam Dadvar, 2012).

Dalam penelitian "The Relationship Between Creative Thinking Ability and Creative Personality of Preschoolers", menunjukkan bahwa terdapat hubungan antara berpikir kreatif dengan kepribadian kreatif pada anak anak prasekolah (Lee, 2005). Penelitian tersebut menunjukkan bahwa ada hubungan antara berpikir kreatif dengan kepribadian kreatif pada anak usia dini. Penelitian ini memiliki implikasi untuk mengidentifikasi anak-anak berbakat dan mengembangkan program pendidikan bagi anak-anak berbakat.

Guilford menyatakan bahwa kreativitas mengacu pada kemamampuan yang menandai seorang kreatif (Ngalimun, dkk, 2013). Menurut NACCCE (National Advisory Committee on Creative and Cultural Education), kreativitas adalah aktivitas imaginatif yang menghasilkan hasil yang baru dan bernilai (Craft, 2005). Kreativitas adalah modifikasi sesuatu yang sudah ada menjadi konsep baru. Dengan kata lain, terdapat dua konsep lama yang dikombinasikan menjadi suatu konsep baru (Semiawan, 2009). Menurut Barron, kreativitas didefinisikan sebagai kemampuan untuk menciptakan sesuatu yang baru (Ngalimun, dkk, 2013). Ciri-ciri kreativitas (Desmita, 2010), antara lain:

a. Mempunyai daya imajinasi yang kuat

b. Senang mencari pengalaman baru

c. Memiliki inisiatif

d. Mempunyai minat yang luas

e. Selalu ingin tahu

f. Mempunyai kebebasan dalam berpikir

g. Mempunyai kepercayaan diri yang kuat

h. Mempunyai rasa humor

i. Penuh semangat

j. Berwawasan masa depan dan berani mengambil resiko.

Kreativitas seseorang akan menciptakan produk kreatif. Produksi kreatif adalah suatu produksi yang baru dan yang tiada tandingannya, serta dikenal dengan kemampuan untuk memproduksi sesuatu yang baru atau menciptakan hubungan baru terhadap sesuatu yang telah diketahui sebelumnya, dengan syarat sesuatu atau hubungan yang baru itu mempunyai tujuan tertentu dan bermanfaat, serta mampu menutupi kebutuhan bagi individu atau sekelompok orang (Abdulssalam, 2005:32). Artinya, anak dapat menghasilkan karya berupa produk yang inovatif dan orisinil dari hasil pemikirannya yang kreatif.

Rogers (dalam Munandar, 2014:18) menyatakan bahwa sumber dari kreativitas adalah kecenderungan untuk mengaktualisasi diri, mewujudkan 
potensi, dorongan untuk berkembang dan menjadi matang, kecenderungan untuk mengekspresikan dan mengaktifkan semua kemampuan organisme.

Menurut Kusumawardani Ratih dkk (2018) bahwa indikator kreativitas anak usia 5-6 Tahun

a. Anak bertanya

b. Anak memiliki daya imajinasi

c. Anak hanya tertarik dengan hal/kegiatan yang itu-itu saja

d. Anak mencoba hal-hal baru

e. Anak bereksplorasi

f. Anak tidak mampu mengatasi perubahan situasi yang terjadi

g. Anak tidak berminat dalam melakukan berbagai hal/kegiatan

h. Anak sulit untuk berkompromi

i. Anak melakukan kegiatan yang unik dengan caranya sendiri

j. Anak melakukan kegiatan yang sama dengan temannya

k. Anak berpendirian kuat

l. Anak melihat suatu masalah dari berbagai sudut pandang

m. Anak lebih suka melakukan hal-hal yang mudah

n. Anak memperlihatkan rasa seni

o. Anak sulit mengungkapkan pendapat terhadap sebuah masalah/kejadian

p. Anak melakukan kegiatan setelah diberikan motivasi

q. Anak memiliki selera humor yang tinggi

Berdasarkan pada teori-teori tentang kreativitas diatas, maka yang dimaksudkan dengan kreativitas yaitu kemampuan anak untuk menciptakan halhal yang baru dapat berupa ide-ide atau pemikiran-pemikiran baru untuk membuat suatu karya sesuai dengan daya imajinasinya.

\section{Mengecap}

Mengecap atau mencetak adalah kegiatan berkarya senirupa dwi marta yang dilakukan dengan cara mencapkan alat atau acuan yang telah diberi tinta ata cat pada bidang gambar (Sumanto, 2005). Suratno (2005) mengungkapkan bahwa kegiatan mencetak pada anak merupakan kesenangan dan penyaluran bakat kreatif pada anak. Mencetak atau seni grafis atau grafika adalah seni rupa yang cetakkannya di kerjakan menggunakan tangan. Sudono Anggani memaparkan mencetak merupakan suatu cara memperbanyak gambar dengan alat cetak atau acuan yang di sebut klise (Masganti, 2016).

Ernawati (2018) bermain mengecat dengan menggunakan bahan alam antara lain berupa batang pepaya buah belimbing, oyong, irisan wortel, irisan kol, kentang dan daun-daunan sangat menarik bagi anak selain itu media bahan alam tidak berbahaya bagi anak, murah dan tidak mengandung bahan kimia apapun. Walaupun demikian anak tetap perlu pendampingan orang tua ketika bermain mengecap di rumah saat menggunakan bahan-bahan dari alam khususnya dari tumbuh-tumbuhan, karena pada tumbuhan tertentu menimbulkan efek gatal, pedas bahkan bisa iritasi. Mengenalkan anak pada alam sekitar serta memanfaatkan bahan sisa untuk pembelajaran, bereksperimen, anak menjadi lebih terampil dan kreatif, anak-anak akan belajar untuk menghargai alam dan kelak mampu menjaga kelestarian alam.

Peran guru di sekolah adalah menyediakan media pembelajaran yang aman, bagi anak dan menarik minat anak, menunjukkan cara menggunakan alat bermain, membimbing anak yang belum menguasai cara mengecap dan memotivasi anak untuk dapat menggunakan media dari bahan alam yang telah disediakan. Belajar pada anak usia dini akan efektif dengan suasana bermain yang 
menyenangkan, anak diberi kesempatan untuk banyak mencoba dan berinovasi dengan bahan alam dalam kegiatan mengecap. Melalui bermain mengecap yang asik anak belajar berkomunikasi dengan temannya, belajar berbagi, mentaati peraturan belajar kerapihan, ketelitian, memperoleh pengetahuan baru, memperluas keahlian berfikir serta meningkatkan kreativitas imajinasi mereka. Para guru mendorong anak-anak untuk memecahkan masalahnya. Seorang anak yang mencampur warna saat mengecap akan terlibat dalam percakapan dengan temannya dan dia menemukan pengetahuan baru, cara mengecap yang baru dan mengajak teman-temannya untuk mengikutinya.

Kegiatan mengecap dengan bahan-bahan dari alam sekitar merupakan salah satu media eksplorasi dan ekspresi yang menyenangkan, anak menjadi lebih kreatif, anak-anak senang bereksperimen dengan bahan dan alat yang beragam serta akan mencoba semua dan teknik baru dengan lebih antusias. Saat anak selesai mengecap, anak akan menceritakan hasil mengecapnya dengan gembira. Dengan demikian selain semakin kreatif kegiatan mengecap dapat berfungsi pula sebagai media komunikasi yang menyenangkan. Anak-anak akan mendapatkan kepuasan batin. Dari hasil karya yang telah dibuatnya, membantu mereka menjadi pribadi yang optimis, percaya diri, kreatif, periang dan berani mencoba hal baru .

Beberapa kegiatan mengecap atau mencetak sederhana yang dapat dilakukan oleh anak usia dini menurut Sumanto (2005:76) sebagai berikut :

a. Mengecap dengan bahan pelepah daun pisang dan pelepah pepaya

Bahan dan alat:

Pelepah daun pisang, batang pepaya, pisau pemotong, pewarna makanan, piring kecil, dan spons.

Cara Kerja:

1) Siapkan adonan warna secukupnya pada piring kecil, kemudian celupkan spons ke dalam adonan warna tersebut.

2) Ambil atau pilih satu atau beberapa potongan pelepah dalam keadaan masih segar (belum layu atau kering) dengan ukuran sedang dan permukaan datar. Pelepah daun pisang dipotong melintang dengan pisau oleh guru(Sumanto, 2005: 76).

3) Kemudian penampang pelepah daun pisang diberi warna dengan cara ditekan pada cairan pewarna atau diolesi dengan memakai kuas atau celupkan salah satu permukaan penampang pelepah pisang atau penampang pelepah pepaya pada spons yang telah diberi warna.

4) Selanjutnya penampang yang sudah bewarna tersebut dicapkan pada kertas yang telah disiapkan sambil dilakukan penataan agar diperoleh hasil cap yang lebih baik dan terarah.

5) Untuk menghasilkan cap dengan komposisi warna tertentu ulangilah langkah mencetak yang sudah dilakukan dengan mencelupkan penampang pada spons bewarna berbeda

b. Mengecap dengan buah-buahan

Bahan dan alat Kegiatan ini menggunakan buah-buahan seperti belimbing yang dipotong melintang, pisau pemotong, pewarna, spons dan kertas kosong.

Cara kerja:

1) Buah belimbing dipotong melintang oleh guru.

2) Permukaan belimbing dicelupkan pada spons pada warna yang diinginkan.

3) Kemudian dicapkan pada kertas sesuai dengan pola yang diinginkan.

4) Untuk menghasilkan cap dengan komposisi warna tertentu ulangi langkah mencetak yang sudah dilakukan dengan mencelupkan buah belimbing pada spons dengan warna berbeda atau sama, sesuai kebutuhan. 


\section{Manfaat Mengecap}

Kegiatan mengecap atau mencetak memiliki manfaat yang sama. Menurut Sumanto (2005: 73) mengatakan bahwa kreativitas mencetak yang dimaksudkan kegiatan berlatih berkarya seni rupa dengan menerapkan cara-cara mencetak/mengecap sesuai tingkat kemampuan anak. Manfaat dari kegiatan mencetak ini adalah dapat mengembangkan kreativitas anak, dapat meningkatkan kemampuan anak dalam mengombinasikan warna (Lerin, 2009: 90).

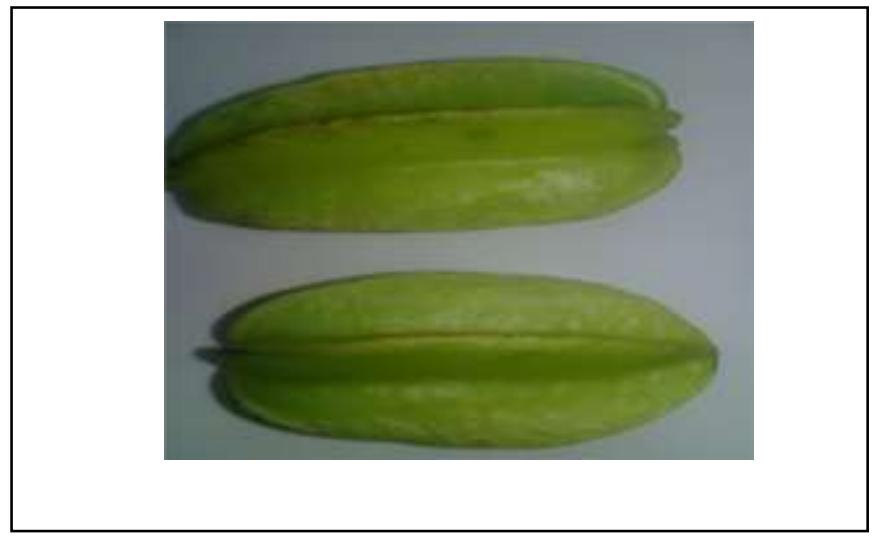

Gambar 1. Buah Belimbing (Averrhoa Carambola)

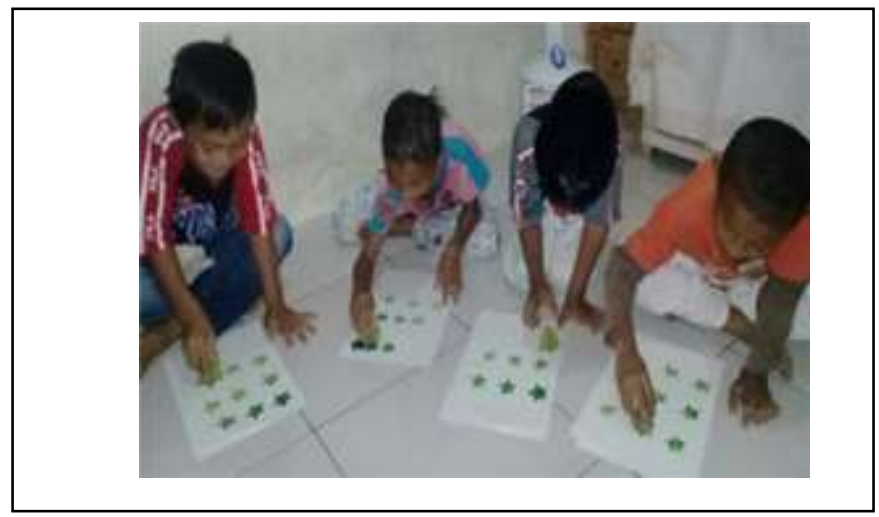

Gambar 2. Kegiatan Mengecap Menggunakan Belimbing

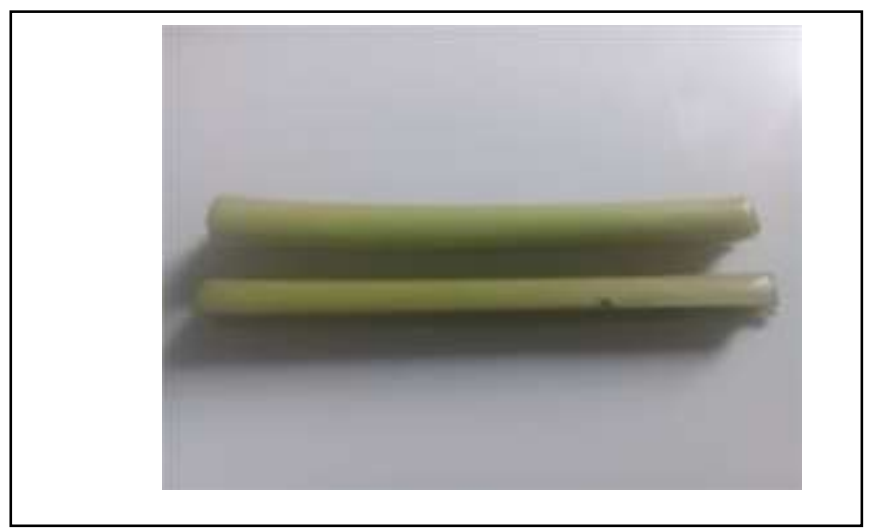

Gambar 3. Pelepah Pisang (Musa Paradisiaca) 


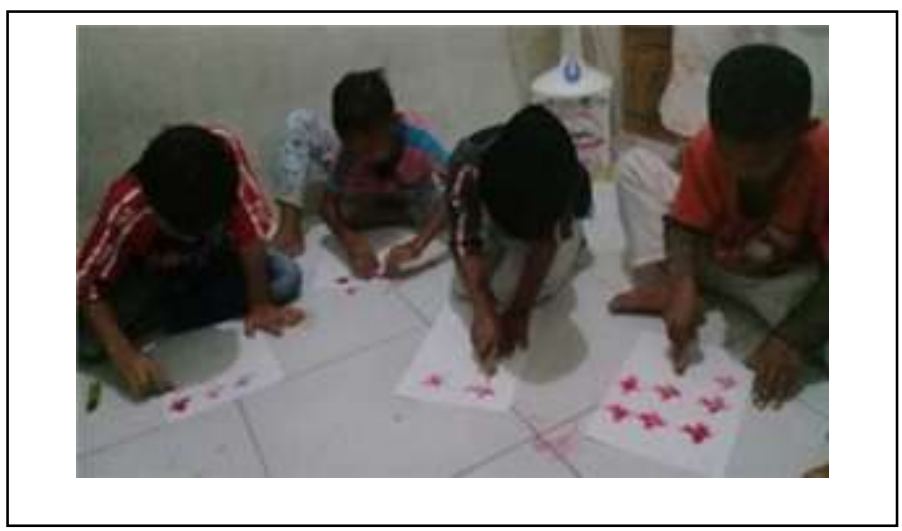

Gambar 4. Mengecap Menggunakan Pelepah Pisang

Berikut ini beberapa penelitian yang terkait dengan kajian yang dilakukan adalah sebagai berikut:

Fauziah (2013) melakukan penelitian dengan tujuan untuk meningkatkan kreativitas anak usia 5-6 tahun melalui penggunaan media bahan alam. Penelitian ini dilaksanakan di PAUD Bestari, Gunung sindur, Bogor, pada bulan November 2012. Metode yang digunakan adalah penelitian tindakan yang dllakukan melalui dua siklus yang terdiri atas perencanaan, tindakan, pengamatan dan refleksi. Subjek penelitian adalah anak PAUD Bestari Gunungsindur yang mempunyai masalah pada kreativitas. Berdasarkan persentase ketercapaian hasil penelitian ini, maka dapat dinyatakan bahwa hipotesis diterima. Dengan demikian, disimpulkan bahwa penggunaan media bahan alam dapat meningkatkan kreativitas anak usia 5-6 tahun.

Juniari dkk, (2016) melakukan Penelitian tindakan Kelas dengan tujuan untuk meningkatkan perkembangan motorik halus anak setelah diterapkannya metode demonstrasi melalui kegiatan mencetak berbantuan bahan alam di kelompok A2 Tk Negeri Pembina Denpasar tahun ajaran 2015/2016. Hasil analisis data menunjukkan bahwa terjadi peningkatan perkembangan motorik halus dari penerapan metode demonstrasi melalui kegiatan mencetak berbantuan bahan alam mencapai 14,19\%. Analisis data dilakukan dengan membandingkan hasil dari siklus I dan siklus II. Pada siklus I diketahui pencapaian perkembangan motorik halus sebesar $66,43 \%$ dengan kategori sedang. Sedangkan pada siklus II pencapaian perkembangan motorik halus sebesar $80,62 \%$ dengan kategori tinggi. Dengan demikian dapat disimpulkan bahwa penerapan metode demonstrasi melalui kegiatan mencetak berbantuan bahan alam dapat meningkatkan perkembangan motorik halus anak kelompok A2 Tk Negeri Pembina Denpasar.

Ristiani dan Badroeni (2017) melakukan penelitian unuk mengetahui peningkatkan kemampuan motorik halus melalui kegiatan mencetak dengan bahan alam di PAUD Nurhanifah Cipondok. Metodologi penelitian ini adalah tindakan kelas di laksanakan melalui 3 siklus dengan tahap tindakan perencanaan, pelaksanaan, observasi, dan refleksi. Berdasarkan hasil observasi tindakan yang dilakukan oleh peneliti pada setiap siklus pada siklus I kategori BB 37,5\%, kategori MB 37,5\%, kategori BSH 25\% dan kategori BSB 0\%, meningkat pada siklus II kategori BB 25\%, kategori MB 12,5\%, kategori BSH 37,5\% dan kategori BSB 12\%, siklus III kategori BB 0\%, kategori MB 6,25\%, kategori BSH 37,5\% dan kategori BSB 56,25\%, kesimpulan dari penilitian ini adalah bahwa kegiatan mencetak dengan bahan alam dapat meningkatkan motorik halus. 
Destiani (2016) melakukan penelitian dan menyimpulkan bahwa pembelajaran dengan teknik mencetak berbantuan media asli dapat meningkatkan kreativitas seni rupa anak kelompok B1 PAUD Aisyiah Bustanul Athfal II Kota Bengkulu dengan hasil pengamatan yang dilakukan mencapai ketuntasan belajar 81,8\% dengan nilai kreativitas keseluruhan 4,21 dengan kriteria baik.

Penelitian yang dilakukan oleh Kolipah Program Studi Pendidikan Guru Pendidikan Anak Usia Dini Fakultas Keguruan Dan Ilmu Pendidikan Universitas Nusantara Pgri Kediri 2015 Skripsi "Meningkatkan Kemampuan motorik Halus Melalui Kegiatan Mengecap Dengan Pelepah Pisang Pada Anak Kelompok B Tk Pkk Pamongan Ii Kecamatan Mojo Kabupaten Kediri". Adapun hasil dari penelitian yang telah dilakukan, dapat diketahui bahwa pada tindakan siklus I ketuntasan belajar anak masih mengecapai 50\%, kemudian setelah dilakukan tindakan perbaikan pada siklus II, ketuntasan belajar anak meningkat menjadi $70 \%$. dan pada tindakan siklus III ketuntasan belajar anak meningkat menjadi 85\%. Dengan demikian, berdasarkan data hasil prosentase ketuntasan dapat diketahui bahwa terdapat peningkatan perolehan nilai kemampuan motorik halus anak setelah dilakukan tindakan perbaikan melalui kegiatan mengecap dengan pelepah pisang.

Penelitian Yang Dilakukan Oleh Istiriyani Program Studi Pendidikan Guru Pendidikan Anak Usia Dini Jurusan Pendidikan Anak Usia Dini Fakultas Ilmu Pendidikan Universitas Negeri Yogyakarta Agustus 2015 Skripsi "Peningkatan Kreativitas Anak Melalui Mencetak Menggunakan Media Pelepah Untuk Anak Kelompok B Tk Pkk 115 Mangiran Bantul Diy". Hasil penelitian pada kondisi awal, kreativitas anak yang mengecapai kriteria berkembang sangat baik baru 3 anak atau $18,75 \%$. Dilanjutkan pada Siklus I kreativitas anak yang mengecapai kriteria berkembang sangat baik meningkat menjadi $56,25 \%$, dan pada Siklus II kreativitas anak yang mengecapai kriteria berkembang sangat baik meningkat lagi menjadi 81,25\%. Dengan demikian, aktivitas mencetak yang dilakukan dengan menggunakan media pelepah dapat meningkatkan kreativitas anak.

Tiwuk (2018) melakukan penelitian PTK yang terdiri dari dua siklus dengan dua pertemuan setiap siklusnya. Anak diajak untuk mencetak dengan media yang berbeda setiap pertemuan untuk meningkatkan kemampuan seni anak. Peningkatan terlihat baik dari segi proses pembelajaran, maupun dari segi hasil. Dari segi proses terlihat dari peningkatan persentase aktifitas guru dan siswa yang secara konsisten meningkat. Dari segi hasil terlihat dari peningkatan persentase jumlah siswa yang memperoleh bintang empat.

Rezieka (2019) melakukan Penelitian Tindakan Kelas (PTK) tentang peningkatan seni karya pada anak dengan penggunaan media bahan alam pelepah pisang. Hasil penelitian pada Siklus I menunjukkan bahwa aktivitas guru 2,0 dengan kriteria Baik dan peningkatan seni karya pada anak 69,31\% dengan kriteria Berkembang Sesuai Harapan (BSH). Pada Siklus II, peningkatan aktivitas guru mencapai 3,94 \% (Sangat Baik) dan peningkatan seni karya pada anak 84,65\% (Berkembang Sangat Baik). Perbandingan hasil penelitian menunjukkan bahwa penggunaan media bahan alam pelepah pisang untuk meningkatkan seni karya pada anak dapat meningkatkan aktivitas guru dan kemampuan anak dalam membuat seni karya.

Irodatul (2019) menemukan hasil penelitian adalah sebagai berikut: 1) Penerapan kegiatan mencetak telah berhasil terbukti. Hal ini dapat dilihat pada hasil penelitian observasi aktivitas anak selama siklus I dan siklus II. Penilaian observasi nilai rata-rata mencetak pada siklus I sebesar 40,38 (Mulai Berkembang) dan pada siklus II sebesar 76,92 (Berkembang Sangat Baik). Perolehan nilai aktivitas anak pada siklus I mendapatkan nilai 35.1 
(Mulai Berkembang) dan siklus II mengalami peningkatan dengan nilai sebesar 69,23 (Berkembang Sesuai Harapan). 2) Adanya kegiatan mencetak digunakan selama proses pembelajaran, hasil persentase ketuntasan belajar dalam meningkatkan Kreativitas anak Berkembang Sesuai Harapan. Persentase ketuntasan Mencetak pada siklus I sebesar 23,07\% (Belum Berkembang) sedangkan siklus II sebesar 84,62\% (Berkembang Sangat Baik). Sedangkan Persentase ketuntasan Kreativitas pada siklus I 23,07 (Belum Berkembang) sedangkan siklus ke II sebusar 84,62\% (Berkembang Sangat Baik).

Berdasarkan pada kajian literatur, mengecap atau mencetak adalah kegiatan seni rupa dua dimensi yang dilakukan dengan cara mencapkan pelepah pisang maupun buah belimbing yang sudah diberi pewarna pada lembaran kertas yang disediakan. Mengecap dari buah belimbing dan pelepah pisang dapat mengembangkan kreativitas anak jika dilakukan terus-menerus. Hal ini terlihat jelas ketika anak dapat dengan leluasa untuk menuangkan ide-ide kreatif mengkreasi hal-hal baru saat membuat cap-cap dari buah belimbing dan pelepah pisang menggunakan kombinasi warna yang menarik serta bentuk-bentuk kombinasi gambar yang dihasilkan dengan teknik mengecap membuat suatu produk yang baru dan manarik sesuai dengan daya imajinasi anak.

\section{Kesimpulan}

Kegiatan mengecap dengan menggunakan buah belimbing dan pelepah pisang berperan dalam mengembangkan kreativitas anak. Ketika anak dilatih untuk mengecap dengan menggunakan buah belimbing dan pelepah pisang secara terusmenerus, maka kemampuan imajinasi anak akan berkembang untuk menuangkan ideide baru, anak mampu berpikir dan membentuk suatu karya yang baru dan menarik.

\section{Daftar Pustaka}

Abdurrahman, J. (2005). Tahapan Mendidik Anak. Bandung: Irsyad Baitus Salam Abdussalam, A. (2005). Mengembangkan kreativitas anak. Jakarta: Pustaka Al-Kautsar.

Bruce, T. (2004). Cultivating creativity in babies, toddlers and young children. London: Hodder Education.

Craft, A. (Ed). (2005). Creativity in Schools Tensions and Dilemmas. New York: Routledge.

Desmita. (2010). Psikologi Perkembangan. Cet. Ke-IV. Bandung: PT. Remaja Rosdakarya Offset

Dadvar, Rahmatollah, Mohammadrezaii, \& Fathabadi, Maryam Habibi. (2012). The Relationship between Emotional Intelligence and Creativity of Female High School Students in Baft City. Journal of Basic and Applied Scientific Research 2(4)4174-4183, 2012 ISSN 2090-4304

Destiani Ardita, Sri Saparahayuningsih, Wembrayarl, 2016. Upaya peningkatan kreativitas seni rupa siswa melalui teknik pencetakan dengan bantuan Media asli, Jurnal Ilmiah Potensia, 2016, Vol.1 (1),7-14

Ernawati Nuring, SPd, (2018). Mengecap Dengan Bahan Alam, Anak Lebih Kreatif Guru Tkit Ulul Albab 2 Purworejo. http://jatengpos.co.id/mengecap-dengan-bahan-alam-anaklebih-kreatif/

Fauziah Nadia, 2013. Penggunaan Media Bahan Alam Untuk Meningkatkan Kreativitas Anak., PG PAUD FIP Universitas Negeri Jakarta, Jurnal Ilmiah VISI P2TK PAUD NI - Vol. 8, No.1, Juni 2013 
Juniari Ni Wayan, Made Putra, Ni Nyoman Ganing. 2016. Penerapan Metode Demonstrasi Melalui Kegiatan Mencetak Berbantuan Bahan Alam Untuk Meningkatkan Perkembangan Motorik Halus. Jurnal Pendidikan Anak Usia Dini Undiksh Vol 4, No 2 (2016)

Kusumawardani, Ratih dkk (2018). Profil Kreativitas Anak Usia 5-6 Tahun FKIP Universitas Sultan Ageng Tirtayasa, Jurnal IImiah VISI PGTK PAUD dan DIKMAS - Vol. 13, No. 1, Juni 2018

Khasanah, Irodatul (2019). Peningkatan Kreativitas Anak Melalui Kegiatan Mencetak (Mengecap) Di Kelompok Bermain Paud Subulus Salam Sarirogo Sidoarjo, Skripsi Universitas Islam Negeri Sunan Ampel Surabaya.

Istiriyani, (2015). Peningkatan Kreativitas Anak Melalui Mencetak Menggunakan Media Pelepah Untuk Anak Kelompok B Tk Pkk 115 Mangiran Bantul Diy, Skripsi Universitas Negeri Yogyakarta

Irodatul Khasanah, 2019. Peningkatan kreativitas anak melalui kegiatan mencetak (mengecap) di kelompok bermain PAUD Subulus Salam Sarirogo Sidoarjo. Undergraduate thesis, UIN Sunan Ampel Surabaya.Digital library, http://digilib.uinsby.ac.id/38887/

Kolipah, (2015). Meningkatkan Kemampuan motorik Halus Melalui Kegiatan Mengecap Dengan Pelepah Pisang Pada Anak Kelompok B Tk Pkk Pamongan II Kecamatan Mojo Kabupaten Kediri, Skripsi Universitas Nusantara PGRI Kediri

Lee, Kyung-Hwa. (2005). The Relationship Between Creative Thinking Ability and Creative Personality of Preschoolers. International Education Journal 6 (2), 1994-199 ISSN 1443-1475. Shannon Research Press

Lestari, B. (2006). Upaya Orang Tua dalam Pengembangan Kreativitas Anak. Jurnal Ekonomi dan Pendidikan, Vol.3 No. 1, April 2006.

Lerin, Christine. (2009). Permainan untuk Meningkatkan Kecerdasan dan Kreativitas Buah Hati. (Alih Bahasa: Heny Fitria Puspita Sari) Jakarta: Transmedia.

Munandar, Utami. 2014. Pengembangan Kreativitas Anak Berbakat. Jakarta: Rineka Cipta.

Munandar Utami, Strategi \& Keberbakatan (Strategi Mewujudkan Potensi Kreativitas \& bakat, Jakarta, Gramedia, 1999.

- Pengembangan Kreativitas Anak Berbakat, Jakarta: Rineka Cipta, 2009

Marisa, Dela (2019). Mengembangkan Kreativitas Anak Melalui Seni Membatik Dengan Mengecap Dari Buah Belimbing Di TK Harapan Ibu Sukarame Bandar Lampung, Skripsi Universitas Islam Negeri Raden Intan Lampung

Masganti Sit, dkk, Pengembangan Kreativitas Anak Usia Dini (Teori dan Praktik), Medan : Perdana Publishing, 2016.

Muninggar, R, Bernadeta, (2014). Peningkatan Kreativitas Melalui Kegiatan Mencetak Pada Kelompok B Di Tk Pertiwi Caturharjo Ngaglik, Caturharjo, Sleman, Skripsi Universitas Negeri Yogyakarta

Ngalimun, dkk. (2013). Perkembangan dan Pengembangan Kreativitas.Yogyakarta: Aswaja Pressindo

Palaniappan, Ananda Kumar. (2006). Academic Achievement of Groups Formed Based on Creativity and Intelligence. Journal. Malaysia: Universty of Malaya

Rezieka Dara Gebrina, 2019. Penggunaan Media Bahan Alam Pelepah Pisang Untuk Meningkatkan Seni Karya Pada Anak Usia 5-6 Tahun Di Tk Bungong Meulu Kecamatan Bubon Kabupaten Aceh Barat.Skripsi thesis, UIN ar-raniry. https://repository.ar-raniry.ac.id/id/eprint/10594/

Ristiani Desi dan Badroeni, 2017. Meningkatkan Kemampuan Motorik Halus Melalui Kegiatan Mencetak dengan Menggunakan Bahan Alam, vol 2 no 1 (2017): jurnal pelita PAUD

Turyani E.M Sri dan Wondal Rosita, (2018). Pengembangan Kreativitas Pembelajaran Pada Anak Usia Dini. Penerbit Chivita Books. 
Supriyadi Dedy, Kreativitas Kebudayaan dan Perkembangan Iptek. Bandung: Alfabeta. 1994. Semiawan, Conny R. (2009). Memupuk Bakat dan Kreativitas Siswa Sekolah Menegah. Jakarta: Gramedia.

Sumanto,(2005). pengembangan kreativitasanak usia TK. Jakarta. Departemen Pendidikan Nasional Direktorat Jenderal Pendidikan Tinggi, Direktorat Pendidikan Tenaga Kependidikan dan Ketenagaan Perguruan Tinggi.

Sumanto. (2005). Pengembangan Kreativitas Seni Rupa Anak TK. Jakarta: Departemen Pendidikan Nasional Direktorat Jenderal Pendidikan Tinggi, Direktorat Pendidikan Tenaga Kependidikan dan Ketenagaan Perguruan Tinggi.

Susanto, Ahmad. 2011. Perkembangan Anak Usia Dini. Jakarta: Kencana

Sit Masganti, dkk. 2016. Pengembangan Kreativitas Anak Usia Dini. Medan: Perdana Publishing.

Suratno, Pengembangan Kreativitas Anak Usia Dini (Jakarta: Depdiknas, 2005)

Sudarso. Jurnal Pendidikan : Riset dan Konseptual, [S.l.], v. 2, n. 4, p. 338-343, oct. 2018. ISSN 2598-2877.

Tiwuk Agustiningsih. 2018. Efektivitas Kegiatan Mencetak dengan Berbagai Media dalam Meningkatkan Kemampuan Dasar Seni Anak pada Kelompok B di TK Yos

Utami Munandar, SCU. 1992. Mengembangkan Bakat dan Kreativitas Anak Sekolah: Petunjuk Bagi Guru dan Orangtua. Jakarta: Depdikbud. 